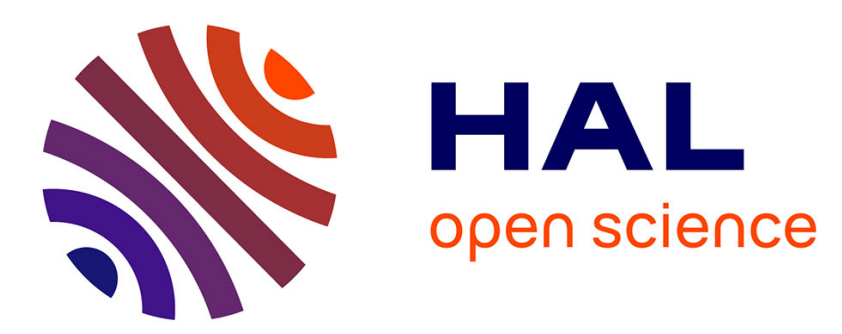

\title{
Endocannabinoids affect the reproductive functions in teleosts and amphibians
}

\author{
E. Cottone, A. Guastalla, K. Mackie, M.F. Franzoni
}

\section{To cite this version:}

E. Cottone, A. Guastalla, K. Mackie, M.F. Franzoni. Endocannabinoids affect the reproductive functions in teleosts and amphibians. Molecular and Cellular Endocrinology, 2008, 286 (1-2), 10.1016/j.mce.2008.01.025 . hal-00531992

\section{HAL Id: hal-00531992 \\ https://hal.science/hal-00531992}

Submitted on 4 Nov 2010

HAL is a multi-disciplinary open access archive for the deposit and dissemination of scientific research documents, whether they are published or not. The documents may come from teaching and research institutions in France or abroad, or from public or private research centers.
L'archive ouverte pluridisciplinaire HAL, est destinée au dépôt et à la diffusion de documents scientifiques de niveau recherche, publiés ou non, émanant des établissements d'enseignement et de recherche français ou étrangers, des laboratoires publics ou privés. 


\section{Accepted Manuscript}

Title: Endocannabinoids affect the reproductive functions in teleosts and amphibians

Authors: E. Cottone, A. Guastalla, K. Mackie, M.F. Franzoni

PII: $\quad$ S0303-7207(08)00031-2

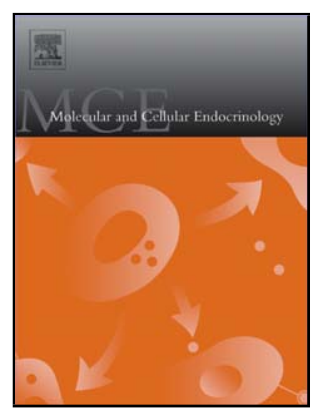

DOI: doi:10.1016/j.mce.2008.01.025

Reference: MCE 6809

To appear in: Molecular and Cellular Endocrinology

Received date:

$10-12-2007$

Revised date:

28-1-2008

Accepted date:

28-1-2008

Please cite this article as: Cottone, E., Guastalla, A., Mackie, K., Franzoni, M.F., Endocannabinoids affect the reproductive functions in teleosts and amphibians, Molecular and Cellular Endocrinology (2007), doi:10.1016/j.mce.2008.01.025

This is a PDF file of an unedited manuscript that has been accepted for publication. As a service to our customers we are providing this early version of the manuscript. The manuscript will undergo copyediting, typesetting, and review of the resulting proof before it is published in its final form. Please note that during the production process errors may be discovered which could affect the content, and all legal disclaimers that apply to the journal pertain. 


\author{
Endocannabinoids affect the reproductive functions in teleosts and amphibians. \\ E. Cottone, A. Guastalla, K. Mackie ${ }^{1)}$, M.F. Franzoni \\ Dipartimento di Biologia Animale e dell'Uomo. Laboratorio di Anatomia Comparata. Università \\ degli Studi di Torino, Via Accademia Albertina 13. I-10123 TORINO \\ 1) Indiana University, 1101 East Tenth Street, Bloomington, IN 47405, USA
}

\begin{abstract}
Following the discovery in the brain of the bonyfish Fugu rubripes of two genes encoding for type 1 cannabinoid receptors (CB1A and CB1B), investigations on the phylogeny of these receptors have indicated that the cannabinergic system is highly conserved. Among the multiple functions modulated by cannabinoids/endocannabinoids through the $\mathrm{CB} 1$ receptors one of the more investigated is the mammalian reproduction. Therefore, since studies performed in animal models other than mammals might provide further insight into the biology of these signalling molecules, the major aim of the present paper was to review the comparative data pointing toward the endocannabinoid involvement in the reproductive control of non mammalian vertebrates, namely bonyfish and amphibians.

The expression and distribution of CB1 receptors were investigated in the CNS and gonads of two teleosts, Pelvicachromis pulcher and Carassius auratus as well as in the anuran amphibians Xenopus laevis and Rana esculenta. In general the large diffusion of neurons targeted by cannabinoids in both fish and amphibian forebrain indicate endocannabinoids as pivotal local messengers in several neural circuits involved in either sensory integrative activities, like the olfactory processes (in amphibians) and food response (in bonyfish), or neuroendocrine machinery (in both). By using immunohistochemistry for $\mathrm{CB} 1$ and $\mathrm{GnRH}$, the codistribution of the two signalling molecules was found in the fish basal telencephalon and preoptic area, which are key centers for gonadotropic regulation in all vertebrates. A similar topographical codistribution was observed also in the septum of the telencephalon in Rana esculenta and Xenopus laevis. Interestingly, the double standard immunofluorescence on the same brain section, aided with a laser confocal microscope, showed that in anurans a subset of GnRH neurons exhibited also the CB1 immunostaining. The fact that CB1-LI-IR was found indeed in the FSH gonadotrophs of the Xenopus pituitary gland and CB1 receptors together with the fatty acid amide hydrolase, the degradative enzyme of the endocannabinoid anandamide, were demonstrated in both bonyfish and frog gonads, strongly suggests that endocannabinoids are involved in central and peripheral gonadotropic functions of teleosts and amphibians.
\end{abstract}


Keywords: CB1, FAAH, GnRH, Double IFL, Immunohistochemistry

Corresponding author: M.F. Franzoni, Dipartimento di Biologia Animale e dell'Uomo. Laboratorio di Anatomia Comparata. Università degli Studi di Torino, Via Accademia Albertina 13. I-10123 TORINO. Tel.: +390116704679

E-mail address: mariafosca.franzoni@unito.it

\section{Contents}

\section{Introduction}

2. Functional relevance of cannabinoid CB1 receptors in teleost and amphibian brains

3. Endocannabinoids affect the reproductive functions in teleosts and amphibians

\section{Concluding remarks}

5. References

\section{Introduction}

From the discovery of two CB1 genes in the brain of the teleost Fugu rubripes by Yamaguchi et al (1996), the comparative investigations on cannabinoid receptors have indicated that this signalling system is conserved through phylogeny. Phylogenetic analysis of CB1 receptor, based on sequence alignment studies performed in several vertebrate and invertebrate species, have indeed corroborated this hypothesis by showing that cannabinoid receptors, although lacking in protostomian invertebrates Drosophila and Coenorhabditis, animal models widely employed in neurobiological investigations, are largely diffused among deuterostomians (Elphick and Egertovà, 2001, 2005).

The presence of the cannabinergic system in most animal groups points out the great relevance of the endocannabinoids in the control of basic physiological activities among which reproduction. From early studies, focusing upon the potent negative effects of Cannabis components on rodent, primate and human pregnancy, the role of cannabinoids stood out in the physiology and pathophysiology of reproduction. Furthermore the potential role of the endocannabinoids in hormonal regulation, embryo implantation and maintenance of pregnancy in both human and other mammals at peripheral and central levels was discussed (Park et al., 2004, Wang et al., 2006). Conversely contributions on the possible involvement of the cannabinergic system in the modulation of non mammal reproduction were scarce.

The aim of the present paper is to review the comparative data, obtained by different research groups, on the involvement of cannabinergic system in teleost and amphibian basic physiological activities, namely reproduction. 
Teleosts are the largest and heterogeneous group of vertebrate characterized by adaptive specializations which reflect their brain neuroanatomy. The amphibian brain, defined by Herrick (1948) the "bauplan" of the high vertebrate brain, is characterized by a simple laminated organization (in contrast with that more elaborated of sauropsid and mammalian brains) which makes it a suitable model to analyse the cannabinergic system into transition between lower and higher vertebrates. Thus, by comparing data obtained in both teleosts and amphibians with those reported for mammals, the mechanisms of action of the cannabinoid signalling system might be better understood even in human.

\section{Functional relevance of cannabinoid CB1 receptors in teleost and amphibian brains}

The cloning of two genes coding for the CB1 receptor subtypes CB1A and B in the bony fish Fugu rubripes (Yamaguchi et al., 1996) represented a true milestone in the cannabinoid comparative investigations. Nevertheless, although bony fish have multiple gene copies in some way related to their evolutionary radiation and phenotypic diversification, at the moment, Fugu and Solea solea (Palermo et al., submitted) are the only teleosts, among those investigated, with two CB1 receptor subtypes. Pelvicachromis pulcher (Cottone et al., 2005a), Carassius auratus (Valenti et al, 2005), Danio rerio (Lam et al., 2006) and Sparus aurata (Ruggeri et al., 2007) are in fact all provided with only one CB1 receptor subtype showing a highest sequence homology with Fugu CB1A.

The distribution of $\mathrm{CB} 1$ receptors has been investigated, by using specific primary antibodies against the rat CB1 (Tsou et al., 1998), in adult brains of both Pelvicachromis pulcher (Cottone et al, 2005a) and goldfish (Valenti et al., 2005), while the CB1 ontogeny was analysed in zebrafish larvae and adults by means of in situ hybridization (Lam et al, 2006). In the adult brains the CB1-likeimmunoreactivity (CB1-LI-IR) was extended through all the telencephalon and a number of CB1 immunostained cell bodies were located immediately below the ventricular ependyma, which is considered a proliferation zone in the adult fish brain (Kirsche, 1967; Ekstrőm et al., 2001; Zupanc and Zupanc, 2006). CB1-LI-IR was observed in the preoptic area, lateral infundibular lobes of the posterior hypothalamus and pituitary gland suggesting that cannabinoids affect neuroendocrine mechanisms. An intense CB1-LI-IR was also detected in the pretectum and nucleus glomerulosus of the posterior tuberculum, both transitional areas between pro- and mesencephalon peculiarly differentiated in teleosts, involved in the integration of visual-motor activities in order to orient fish toward preys and elicite appetite (Demski, 1973; Roberts and Savage, 1978; Demski and Northcutt, 1983). The involvement of endocannabinoids in the goldfish feeding responses was indeed recently reported by Valenti et al. (2005). On the other hand a similar role was postulated for endocannabinoids in very simple living organisms like Hydra (Cnidaria) (De Petrocellis et al., 1999) 
and the sea squirt Ciona intestinalis (Matias et al., 2005) suggesting that the cannabinergic involvement in feeding state is phylogenetically ancient.

The in situ hybridization for CB1 mRNA on zebrafish larvae brain (Lam et al., 2006) has shown an early CB1 expression in the preoptic area and, later, within the dorsal telencephalon and mesodiencephalon, brain areas rich in CB1 in the adult teleosts (Cottone et al., 2005a; Valenti et al., 2005; Lam et al., 2006). In postembryonic larvae CB1 distribution is closely resembling the adult one and the prosencephalic cannabinergic innervation is topographically related to areas interested by the concomitant differentiation of classic neurotransmitter systems (GABA, Dopamine), accordingly to what reported in the fetal brains of human and rat (Fernandez-Ruiz et al., 2004).

The first report on the occurrence of the cannabinergic system in the amphibian CNS concerned the pharmacological and molecular characterization of CB1 receptors in a urodele amphibian, the Taricha granulosa (Soderström et al., 2000). The CB1 was then cloned and characterized in the anuran Xenopus laevis CNS (Cottone et al., 2003) and, comparing the CB1 amino acid sequence alignments of the two amphibian species with those of other vertebrates, man included, a high degree $(83 \%)$ of molecular homology between the CB1 primary structures of amphibians and mammals has been found.

The distribution of CB1 was investigated in the CNS of adults and embryos/larvae of Xenopus laevis (Cesa et al., 2001; Beatrice et al., 2006) and Rana esculenta (Donna et al., 2006) and many similarities with mammalian CB1 distribution (Tsou et al., 1998) were shown. By using the double immunofluorescence technique on the same brain section, aided by confocal laser microscope, relationships between $\mathrm{CB} 1$ and other signalling molecules were analysed in Xenopus CNS. In particular CB1-LI-IR was found to co-exist with GABA immunolabelling in a number of periglomerular cells of the olfactory bulb (Cesa et al., 2001), with GABA-, SP- and $\mu$ opioid receptor-LI-IRs in the spinal cord (Salio et al., 2002). Moreover the CB1 receptors were detected in lactotrophs, gonadotrophs and thyrotrophs of the pituitary gland (Cesa et al., 2002).

On the basis of their neuroanatomical distribution (Cesa et al., 2001; Cottone et al., 2003; Hollis et al., 2006) and relationship with a number of other signalling molecules (Cesa et al., 2001; Salio et al., 2002; Guastalla et al., 2006) the amphibian CB1 cannabinoid receptors were mainly considered modulators in sensory and sensorimotor integrations, endocrine and behavioral outputs. Moreover, since the intense CB1 mRNA ISH staining found in Taricha amigdaloid complex (Hollis et al., 2006) well matched the strong CB1-LI-IR and mRNA expression in the corresponding nucleus of Xenopus (Cesa et al., 2001; Cottone et al., 2003), the cannabinergic modulation of fear, anxiety and stress responses was postulated. 


\section{Endocannabinoids affect the reproductive functions in teleosts and amphibians}

The potent negative cannabinoid effects upon both experimental animal and human reproduction are largely documented (see the reviews of Park et al., 2004 and Wang et al., 2006). Since the CB1 receptors were detected in the Leydig cells of the mouse testis and the endogenous cannabinoid anandamide (AEA) was shown to suppress serum LH and testosterone levels in normal but not in CB1 knockout animals, Wenger et al. (2001) postulated that cannabinoids do modulate reproductive functions at peripheral and central levels.

Basic components of the cannabinergic system like the CB1 receptors and the fatty acid amide hydrolase (FAAH), the degradative enzyme of AEA, were found and characterized not only in the teleost and amphibian brain but also in the gonads. CB1 mRNA expression was in fact detected in the gonads of Carassius auratus, Pelvicachromis pulcher, Rana esculenta and Xenopus laevis (Fig. 1), as well as Sparus aurata (Ruggeri et al., 2007).

In the frog gonads (Cobellis et al., 2006) the occurrence of both CB1 receptors and FAAH was reported, in agreement with the observations performed in rodent males (Cobellis et al., 2006). In Xenopus laevis pituitary the CB1-LI-IR was found in the FSH gonadotropic cells (Cesa et al., 2002). Moreover in the frog brain the CB1 expression profile was characterized during the annual sexual cycle by fluctuations possibly related to gonadal activity (Meccariello et al., 2006 and submitted).

Recently Gammon et al. (2005) have shown that immortalized hypothalamic GnRH neurons are capable of releasing endogenous cannabinoids such as AEA and 2-arachydonoilglycerol and possess $\mathrm{CB} 1$ and $\mathrm{CB} 2$ receptors suggesting a novel neural control of mammalianGnRH release. To analyse possible morphofunctional relationships between $\mathrm{CB} 1$ and $\mathrm{GnRH}$, key molecule in the gonadotropic regulation of all vertebrates, serial sections of the basal telencephalon and the rostral preoptic area were immunohistochemically investigated in both teleosts (Cottone et al., 2005b) and amphibians (Guastalla et al., 2006; Donna et al., 2006; Meccariello et al., submitted).

In consecutive brain sections of both Pelvicachromis pulcher and Carassius auratus, stained with the primary antibodies raised against $\mathrm{CB} 1$ receptor and salmon $\mathrm{GnRH}$ respectively, a close contiguity between CB1-LI- and salmonGnRH-LI-immunoreactive cell bodies and nerve fibers was observed in the basal telencephalon (Fig. 2) and preoptic area.

In the brain of Rana esculenta and Xenopus laevis the co-distribution of CB1-LI- and mammalianGnRH-LI-IRs occurred in areas corresponding to those described in the above teleost species. To investigate the possible co-existence of the two molecules, we employed on the same sections the double standard immunofluorescence technique, aided by a laser scanning confocal microscope. Interestingly, a subset of frog GnRH immunoreactive neurons in the septum and preoptic area (roughly estimated as the $20 \%$ of the GnRH neurons) together with nerve fibers and 
terminals in the median eminence of the neurohypophysis, showed simultaneous double $\mathrm{CB} 1+/ m \mathrm{GnRH}+-\mathrm{LI}-\mathrm{IR}$ (Fig. 3) suggesting morphofunctional correlations between endogenous cannabinoids and GnRH, mediated by CB1.

\section{Concluding remarks}

All data reported in fish and amphibian brains strongly point out the functional relevance of the endocannabinoids as local messengers in several neural circuits as reported after pharmacological (Soderström et al., 2000; Valenti et al., 2005; Hollis et al., 2006) and behavioural (Soderström et al., 2000) approaches. Our observations support the hypothesis that amphibian GnRH neurons might be tuned by the endocannabinoids through CB1 (Guastalla et al., 2006). The occurrence of a cannabinergic modulation of GnRH release is supported by semiquantitative analysis showing that the fluctuations of $\mathrm{GnRH}$ expression in the frog brain clearly mismatch, during the annual sexual cycle, the expression profile of CB1, especially in the telencephalon and diencephalon which are the areas mainly involved in GnRH release (Meccariello et al., submitted).

Although the general physiological role of endocannabinoids is far from being understood in non mammalian vertebrates, the investigations in organisms different from mammals might provide new insight into the cannabinoid biology. Basic information on the cannabinergic system derived from comparative investigations in simple CNS of invertebrates and/or lower vertebrates, could in fact contribute to better understand the mechanisms of action of such molecules in mammals and also stimulate the development of new strategies for their therapeutic use in human.

\section{References}

Beatrice, M., Gabriella, M., Francesca, G., Oliana, C., 2006. Endocannabinoid system in Xenopus laevis development: CB1 receptor dynamics. FEBS Lett. 580, 1941-1945.

Cesa, R., Mackie, K., Beltramo, M., Franzoni, M.F., 2001. Cannabinoid receptor CB1-like and glutamic acid decarboxylase-like immunoreactivities in the brain of Xenopus laevis. Cell Tiss. Res. 306, 391-398.

Cesa, R., Guastalla, A., Cottone, E., Mackie, K., Beltramo, M., Franzoni, M.F., 2002. Relationships between CB1 cannabinoid receptors and pituitary endocrine cells in Xenopus laevis: an immunihistochemical study. Gen. Comp. Endocrinol. 125, 17-24.

Cobellis, G., Cacciola, G., Scarpa, D., Meccariello, R., Chianese, R., Franzoni, M.F., Mackie, K., Pierantoni, R., Fasano, S., 2006. Endocannabinoid system in frog and rodent testis: Type-1 cannabinoid receptor and fatty acid hydrolase activity in male germ cells. Biol. Reprod. 75, 82-89.

Cottone, E., Salio, C., Conrath, M., Franzoni, M.F., 2003. Xenopus laevis CB1 cannabinoid receptor: 
molecular cloning and mRNA distribution in the central nervous system. J. Comp. Neurol. 464, 487496.

Cottone, E., Forno, S., Campantico, E., Guastalla, A., Viltono, L., Mackie, K., Franzoni M.F., $2005 a$. Expression and distribution of CB1 cannabinoid receptors in the central nervous system of the African cichlid fish Pelvicachromis pulcher. J. Comp. Neurol. 485, 293-303.

Cottone, E., Campantico, E., Guastalla, A., Aramu, S., Polzonetti-Magni, A., Franzoni, M.F., $2005 b$. Are the cannabinoids involved in fish reproduction? Ann. N .Y. Acad. Sci. 1040, 1-4.

De Petrocellis, L., Melck, D., Bisogno, T., Milone, A., Di Marzo, V., 1999. Finding of the endocannabinoid signalling system in Hydra, a very primitive organism: possible role in the feeding response. Neuroscience 92, 377-387.

Demski, LS., 1973. Feeding and aggressive behavior evoked by hypothalamic stimulation in a cichlid fish. Comp. Biochem. Physiol. 44, 685-692.

Demski, L.S., Northcutt, R.G., 1983. The terminal nerve: a new chemosensory system in vertebrates?. Science 220, 435-437.

Donna, D., Cottone, E., Aramu, S., Campantico, E., Guastalla, A., Franzoni, M.F., 2006. Endocannabinoids and amphibian reproduction: an immunohistochemical study in the green frog. Acc. Sc. Torino -Atti Sc. Fis. 140, 37-45.

Ekstrom, P., Johnsson, C.M., Ohlin, L.M., 2001. Ventricular proliferation zones in the brain of an adult teleost fish and their relation to neuromeres and migration (secondary matrix) zones. J. Comp. Neurol. 436, 92-110.

Elphick, M.R., Egertovà, M., 2001.The neurobiology and evolution of cannabinoid signalling. Phil. Trans. R. Soc. Lond. B 356, 381-408.

Elphick, M.R., Egertovà, M., 2005. The phylogenetic distribution and evolutionary origins of endocannabinoid signalling. Handb. Exp. Pharmacol. 168, 283-97.

Fernández-Ruiz, J., Gómez, M., Hernández, M., de Miguel, R., Ramos, J.A., 2004. Cannabinoids and gene expression during brain development. Neurotox. Res. 6, 389-401.

Gammon, C.M., Freeman, G.M. Jr, Xie, W., Petersen, S.L., Wetsel, W.C., 2005. Regulation of gonadotropin-releasing hormone secretion by cannabinoids. Endocrinology 146, 10, 4491-9.

Guastalla, A., Aramu, S., Donna, D., Cottone, E., Campantico, E., Mackie, K., Wray, S., Franzoni, MF., 2006. A possibile crosstalk between endocannabinoids and GnRH neurons: An immunohistochemical study in the amphibian brain. Front. Neuroendocrinol. 27, 31.

Herrick, C.J., 1948. The Brain of the Tiger Salamander. The University of Chicago Press, Chicago, Illinois.

Hollis, D.M., Coddington, E.J., Moore, F.L., 2006. Neuroanatomical distribution of cannabinoid receptor gene expression in the brain of the rough-skinned newt Taricha granulosa. Brain Behav. Evol. 67, 135-149. 
Kirsche, W., 1967. Über postembryonale matrixzonen im gehirn verschiedener vertebraten und deren beziehung zur hirnbauplahnlehere. Z. Mikrosk-Anat. Forsch. 77, 313-406.

Lam, C.S., Rastegar, S., Strähle U., 2006. Distribution of cannabinoid receptor 1 in the CNS of zebrafish. Neuroscience, 138, 83-95.

Matias, I., Mc Partland, J.M., Di Marzo, V., 2005. Occurrence and possible biological role of the endocannabinoid system in the sea squirt Ciona intestinalis. J. Neurochem. 93, 1141-1156.

Meccariello, R., Chianese, R., Cacciola, G., Cobellis, G., Pierantoni, R., Fasano, S., 2005. Type-1 cannabinoid receptor expression in the frog, Rana esculenta, tissues: a possible involvement in the regulation of testicular activity. Mol. Reprod. Dev. 73,551-558.

Park, B., McPartland, J.M., Glass, M., 2004. Cannabis, cannabinoids and reproduction. Prostagl. Leukot. Essent. Fatty Acids 70, 189-197.

Roberts, M.G., Savage, G.E., 1978. Effects of hypothalamic lesions on the food intake of the goldfish (Carassius auratus). Brain Behav. Evol. 15, 150-164.

Ruggeri, B., Soverchia, L., Mosconi, G., Franzoni, M.F., Cottone, E., Polzonetti-Magni, A.M., 2007. Changes of gonadal CB1 cannabinoid receptor mRNA in the gilthead seabream, Sparus aurata, during sex reversal. Gen. Comp. Endocrinol. 150, 263-269.

Salio, C., Cottone, E., Conrath, M., Franzoni, M.F., 2002. CB1 cannabinoid receptors in amphibian spinal cord: relationships with some nociception markers. J. Chem. Neuroanat. 24,153-162.

Soderstrőm, K., Leid, M., Moore, F.L., Murray, T.F., 2000. Behaviroal, pharmacological, and molecular characterization of an amphibian cannabinoid receptor. J. Neurochem., 75, 413- 423.

Tsou, K., Brown, S., Sanudo-Pena M.C., Mackie, K.,Walker, J.M., 1998. Immunohistochemical distribution of cannabinoid CB1 receptors in the rat central nervous system. Neuroscience, 83, 393411.

Valenti, M., Cottone, E., Martinez, R., De Pedro, N., Rubio, M., Viveros, M.P., Franzoni, M.F., Delgado, M.J., Di Marzo, V., 2005. The endocannabinoid system in the brain of Carassius auratus and its possible role in the control of food intake. J. Neurochem. 95, 662-672.

Wang, H., Dey, S.K., Maccarrone, M., 2006. Jekyll and Hyde: two faces of cannabinoid signalling in male and female fertility. Endocr. Rev. 5, 427-448.

Wenger, T., Ledent, C., Csernus, V., Gerendai, I., 2001. The central cannabinoid receptor inactivation suppresses endocrine reproductive functions. Biochem. Biophys. Res. Commun. 284,3 63-368.

Yamaguchi, F., Macrae, A. D., Brenner, S., 1996. Molecular cloning of two cannabinoid type 1-like receptor genes from the puffer fish Fugu rubripes. Genomics, 35, 603-605.

Zupanc, G.K., Zupanc, M.M., 2006. New neurons for the injured brain: mechanisms of neuronal regeneration in adult teleost fish. Reg. Med. 1, 207-216. 


\section{Figure legends}

\section{Figure 1.}

CB1 expression in fish and amphibian CNS and gonads.

Semiquantitative RT-PCR was performed using specific primers designed on the basis of the different CB1 sequences (GenBank accession numbers: Carassius auratus AY674057, Pelvicachromis pulcher $\mathbf{\text { AY585342}}$, Rana esculenta AM113546, Xenopus laevis AY098532). The housekeeping genes used were $\beta$-actin for Carassius auratus and Pelvicachromis pulcher and GAPDH for Rana esculenta and Xenopus laevis. CB1 mRNA is expressed in the CNS and, to a lesser extent, in the gonads of all the species considered.

\section{Figure 2.}

$\mathrm{CB} 1 / s \mathrm{GnRH}$ immunoreactivities in the Pelvicachromis pulcher basal telencephalon.

Two consecutive sections showing A) CB1-LI-IR cell bodies (arrows) codistributed, in the ventral septum, with B) $s$ GnRH-LI-IR neurons (arrows). In A) a number of periventricular CB1-LI-IR neurons (arrowheads) and a lateral cannabinergic innervation are also observed. $\mathrm{v}=$ ventricle.

Biotin-avidin system immunohistochemistry. Scale bars: $100 \mu \mathrm{m}$.

\section{Figure 3.}

$\mathrm{CB} 1 / m \mathrm{GnRH}$ immunoreactivities in the Xenopus laevis forebrain sections.

A) In the preoptic area a CB1 immunopositive (red fluorescence) cell body (arrow) and nerve fibres and terminals, some of which presumably surrounding an immunonegative neuron (arrowhead), are shown. B) The same CB1+ neuron (arrow), as well as the terminals indicated by the arrowhead, are also mammalianGnRH-immunopositive (green fluorescence). C) Merging of A) and B) showing in yellow the double labellings. D) In the median eminence a number of fibres and terminals are CB1immunopositive. E) In the same section of D) an abundant GnRH-immunoreactivity is observed. F) Merging of D) and E) showing in yellow the double labelled terminals. Inf=infundibulum. Standard double immunofluorescence (IFL), aided by a laser scanning confocal microscope. Scale bars: 20 $\mu \mathrm{m}$. 
Acknowledgments: Grants from MURST (COFIN 2003/2003059955-002 and ex 60\%/2005/2006 to MFF) 


$\frac{\text { Carassius auratus }}{\text { CNS ovary testis }} \frac{\text { Pelwicachromis pulcher }}{\text { CNS ovary testis }} \frac{\text { Rana esculenta }}{\text { CNS ovary testis }} \frac{\text { Xenopus laevis }}{\mathrm{CNS} \text { ovary }}$

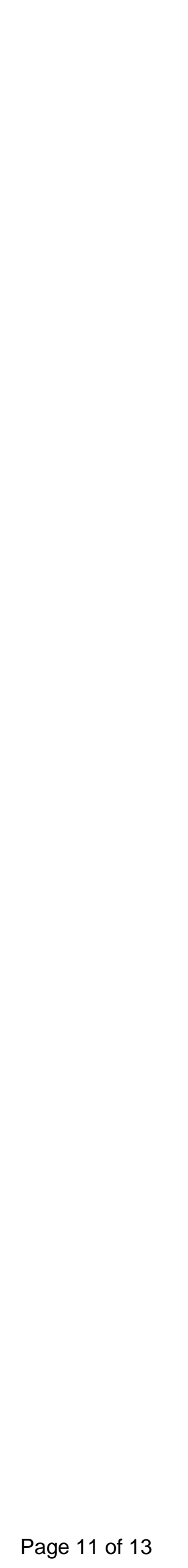

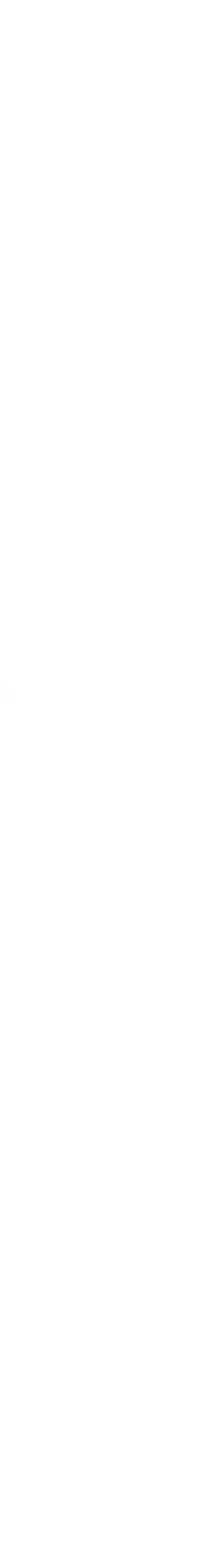



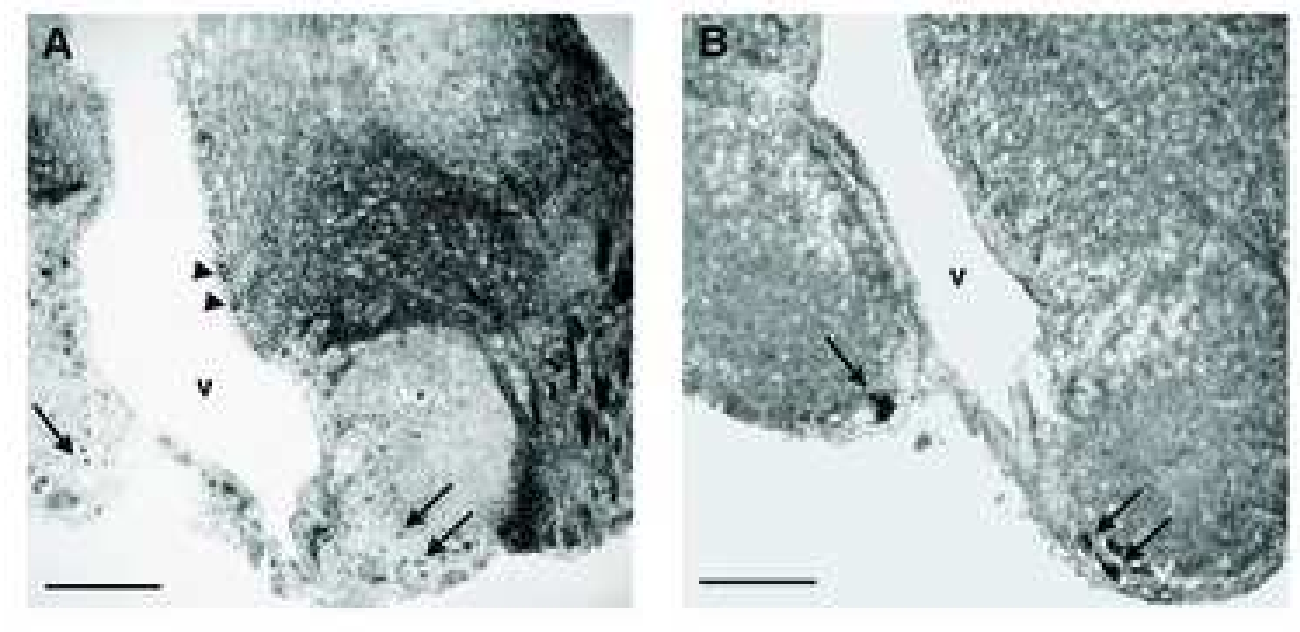

Page 12 of 13

Figure 2 

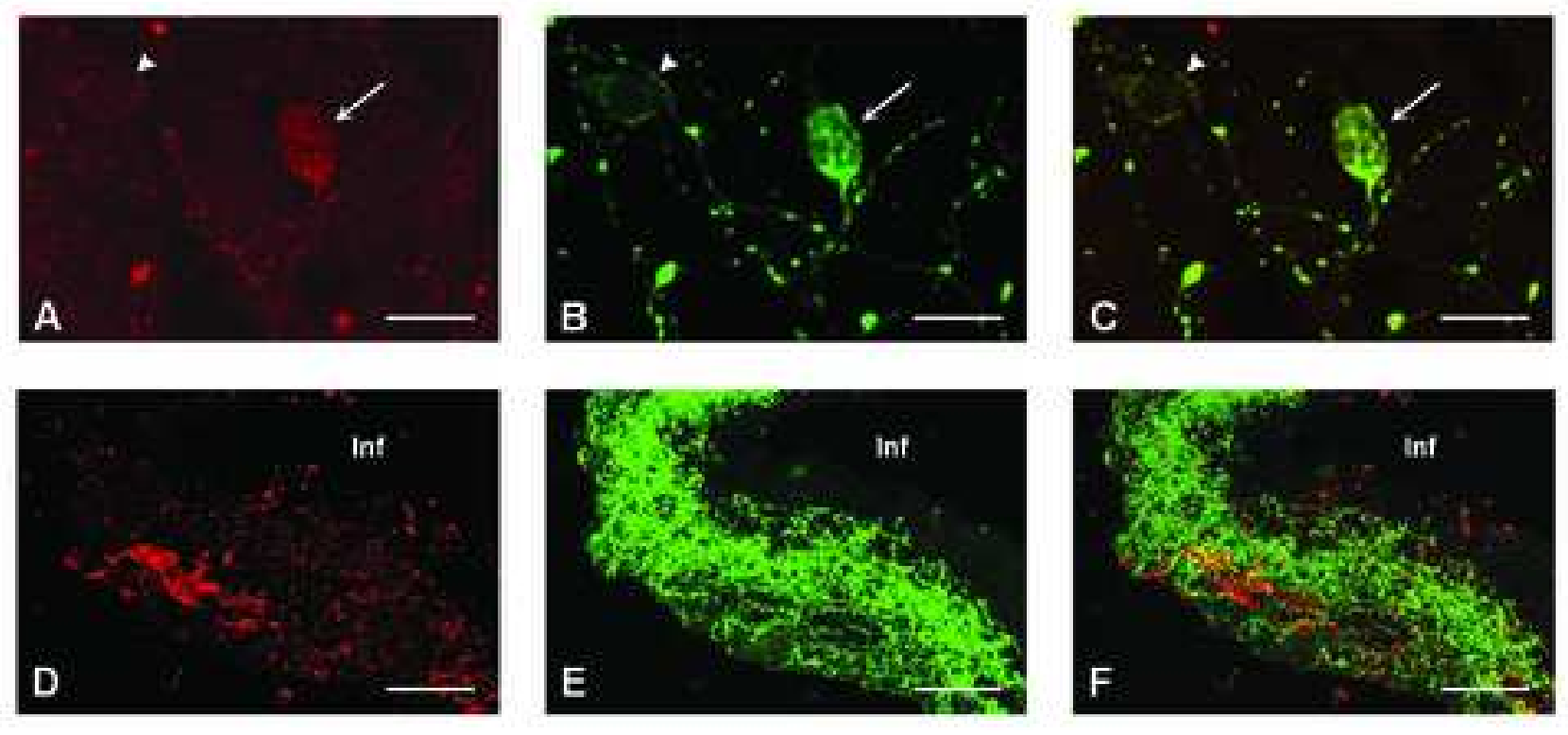

Page 13 of 13 